due to underlying duct ectasia or chronic breast disease provides a suitable nidus for the deposition of these anaerobes.

${ }^{1}$ Leach RD, Eykyn SJ, Phillips I, Corrin B. Anaerobic subareolar breast abscess. Lancet 1979; i:35-7.

2 Wilson WR, Martin WJ, Wilkawske CJ, Washington JA. Anaerobic bacteremia. Mayo Clin Proc 1972;47:639-46.

3 Lefrock JL, Ellis CA, Turchik JB, Weinstein L. Transient bacteremia associated with sigmoidoscopy. N Engl F Med 1973;289:467-9.

(Accepted 1 December 1980)

St Thomas's Hospital, London SE1 7EH

R D LEACH, MB, FRCS, honorary senior registrar, surgical unit (now lecturer in surgery, Westminster Medical School)

SUSANNAH J EYKYN, MB, MRCPATH, senior lecturer

IAN PHILLIPS, MD, MRCPATH, professor of microbiology

\section{Treatment of biliary duct stones with a terpene preparation}

Biliary duct stones are often found in patients who present with gallbladder disease and are poor surgical risks. Retained stones may persist after cholecystectomy, despite recent developments in nonoperative methods of extraction and in-situ litholytic agents. When facilities for endoscopic „papillotomy are lacking, reoperation is contraindicated or further procedures refused, and spontaneous passage is unlikely on grounds of stone size, an alternative approach is needed. We used Rowachol (Rowa Ltd, Bantry, Ireland), a monoterpene mixture with cholelitholytic potential.

\section{Patients, methods, and results}

We treated nine female and two male patients with radiotranslucent ductal stones of a diameter greater than $7 \mathrm{~mm}$ and absent, infrequent, or mild symptoms (group 1) and four postoperative patients with retained stones, whose elective reoperations were either refused or considered to be undesirable (group 2). Endoscopic papillotomy was not available at the start of the study. In group 1 three patients had previously undergone cholecystectomy and three had, or developed, non-functioning gall bladders.

Maintenance dosage of Rowachol was with three capsules daily (some patients started at higher doses); symptoms and liver function were monitored six-weekly. Intravenous cholangiography was repeated after six and 12 months.

Treatment was well tolerated, a slightly sore mouth in one case being the only side effect. Results of liver function tests remained normal in six patients and improved in four asymptomatic patients with initially abnormal values. Five patients developed transient abnormalities after attacks of colic or jaundice.

The two male patients were withdrawn, one after five months when surgery was recommended for increasing colic and jaundice, the other after seven months on his death from cardiac infarction. Thirteen patients, all female, took Rowachol for one year or until the stone dissolved, if this was earlier. One of these had bile-duct dilatation and recurrent jaundice; after repeated advice she eventually accepted surgery, but at cholecystectomy no duct stones were found. The table shows details of gall-stone dissolution. One patient is not included because inadequate radiography precluded assessment. Of the four non-responders, two had large calculi after cholecystectomy 30 years previously.

\section{Comment}

The results of treating common bile duct stones with Rowachol are encouraging and compare well with published results obtained using bile-acid treatment. The best reported success rate achieved using chenodeoxycholic acid is five out of eight cases $(62.5 \%),{ }^{2}$ but other series of patients have fared less well. Bateson et al had only one success in 10 cases and reported a high incidence of severe symptoms. ${ }^{3}$ Most of our patients presented with biliary symptoms, but only two required surgery during treatment with Rowachol, which suggests that the antispasmodic properties of the constituent terpenes ${ }^{4}$ may be of value. Rowachol also has the advantages of low cost and virtual absence of side effects. Thus, when other treatments for ductal stones are unacceptable or impracticable and long-term medical treatment is indicated, we suggest that Rowachol should be used, possibly in combination with small doses of chenic acid, which is our present practice. Such management in no way precludes subsequent definitive treatment by surgery or other methods should this become available or desirable; indeed, two of the patients described above subsequently underwent endoscopic papillotomy.

Response of biliary duct stones to treatment with Rowachol

\begin{tabular}{ccccc}
\hline $\begin{array}{c}\text { Duration of } \\
\text { treatment }\end{array}$ & $\begin{array}{c}\text { No of } \\
\text { patients } \\
\text { treated }\end{array}$ & $\begin{array}{c}\text { No with } \\
\text { partial } \\
\text { dissolution } \dagger\end{array}$ & $\begin{array}{c}\text { No with } \\
\text { complete } \\
\text { disappearance }\end{array}$ & $\begin{array}{c}\text { Response } \\
\text { rate }\end{array}$ \\
\hline 6 months & $13 *$ & 2 & 4 & $6 / 13(46 \%)$ \\
12 months & $12^{*}$ & 2 & 6 & $8 / 12(67 \%)$ \\
\hline
\end{tabular}

*Includes patients treated for less than 12 months but until the stones disappeared. tReduction in size or number of stones.

The reasons why Rowachol should be more successful in ductal than gall-bladder ${ }^{5}$ disease are not clear. A flushing effect of the choleresis for which Rowachol is marketed may be contributory.

Full details of the patients and the results of liver function tests are available on request from Dr G D Bell, University Department of Therapeutics, City Hospital, Nottingham NG5 1PD.

${ }^{1}$ Doran J, Keighley MRB, Bell GD. Rowachol-a possible treatment for cholesterol gallstones. Gut 1979;20:312-7.

2 Barbara L, Roda E, Roda A, et al. The medical treatment of cholesterol gallstones: experience with chenodeoxycholic acid. Digestion 1976;14: 209-19.

${ }^{3}$ Bateson MC, Ross PE, Murison J, Bouchier IAD. Comparison of fixed doses of chenodeoxycholic acid for gallstone dissolution. Lancet 1978; : 1111-4.

4 Boettge K. Ätherische Öle und Spasmolyse. Med Monatsschr 1954 ;8:444-6.

5 Ellis WR, Bell GD. Rowachol treatment for gallstones-small doses are best. Gut 1979;20:A931.

(Accepted 21 November 1980)

University Department of Therapeutics, City Hospital, Nottingham NG5 1PD

W R ELLIS, MA, MRCP, research fellow and honorary senior registrar G D BELL, MD, MRCP, senior lecturer

\section{Adjunct to bile-acid treatment for gall-stone dissolution: low-dose chenodeoxycholic acid combined with a terpene preparation}

Chenodeoxycholic acid is an established treatment for cholesterol gall stones. Bile is desaturated by reducing the output of cholesterol relative to bile acids; possible mechanisms of action include inhibition of hepatic S-3-hydroxy-3-methylglutaryl coenzyme A reductase (HMGR), the rate-limiting enzyme for cholesterol synthesis. ${ }^{12}$

The recommended dose of chenodeoxycholic acid $(15 \mathrm{mg} / \mathrm{kg} /$ day $)$ causes diarrhoea in one-third of cases; reduction in dosage may alleviate this problem, but treatment is ineffective in doses of under $500 \mathrm{mg}$ daily. ${ }^{1}$ When full dosage is tolerated response rates are poor in obese patients and when stone diameter exceeds $15 \mathrm{~mm} .{ }^{2} \mathrm{~A}$ further serious disadvantage of chenodeoxycholic acid is its cost (over $£ 600$ per year for a $70 \mathrm{~kg}$ man at $15 \mathrm{mg} / \mathrm{kg} /$ day). Adjuvant treatments such as phenobarbitone, $\beta$-sitosterol, and restriction of dietary cholesterol have hitherto either failed to increase the efficacy of chenodeoxycholic acid (and thus reduce cost and side effects) or given only marginal benefit. ${ }^{1}$

Rowachol (Rowa Ltd, Bantry, Ireland) is a well-tolerated, inexpensive preparation containing six cyclic monoterpenes: it inhibits hepatic $\mathrm{HMGR},{ }^{3}$ alters biliary cholesterol saturation, ${ }^{4}$ and can dissolve gall stones but is more effective in low than high dosage. ${ }^{45}$ This may reflect differences in the effects of individual constituent terpenes on HMGR. ${ }^{3}$ We report our experience of using Rowachol in combination with a small (and hence on its own probably ineffective $)^{12}$ dose of chenodeoxycholic acid in an unselected series of patients with gall stones. 